\title{
Transatlantica
}

Revue d'études américaines. American Studies Journal

\section{Indiscipline, or, The Condition of Comics Studies}

\section{Charles Hatfield}

\section{(2) OpenEdition}

Journals

Édition électronique

URL : https://journals.openedition.org/transatlantica/4933

DOI : $10.4000 /$ transatlantica.4933

ISSN : 1765-2766

Éditeur

Association française d'Etudes Américaines (AFEA)

Référence électronique

Charles Hatfield, «Indiscipline, or, The Condition of Comics Studies », Transatlantica [En ligne], 1 | 2010, mis en ligne le 27 septembre 2010, consulté le 10 février 2023. URL : http://journals.openedition.org/ transatlantica/4933; DOI : https://doi.org/10.4000/transatlantica.4933

Ce document a été généré automatiquement le 10 février 2023.

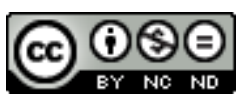

Creative Commons - Attribution - Pas d'Utilisation Commerciale - Pas de Modification 4.0 International - CC BY-NC-ND 4.0

https://creativecommons.org/licenses/by-nc-nd/4.0/ 


\title{
Indiscipline, or, The Condition of Comics Studies
}

\author{
Charles Hatfield
}

1 "The structure of the research university needs serious rethinking," says James Chandler, in his contribution to Critical Inquiry's 2003 symposium on "The Future of Criticism." Calling for, à la Foucault, a historical epistemology of the academic disciplines and indeed the very concept of disciplinarity, Chandler hopes for both "a more rigorous account of what a discipline is" and the exploration of "new possibilities for interdisciplinary connection and exploration" (359). This essay will, if not precisely answer Chandler's call, then undertake a self-reflexive examination of the issue of disciplinarity in academic comics studies, particularly in North America. In the process, I hope to explain why comics studies, which is already inevitably multidisciplinary, must work toward a model of true interdisciplinary collaboration if the field is to thrive.

2 As this issue of Transatlantica attests, and as the growing number of journal issues, articles, and books devoted to comics confirm, comics studies in North America constitutes a nascent academic field of great productivity and promise. Indeed by now one might expect and hope that the field would qualify as something more than "nascent." Certainly much work has been done, horizons for future work have begun to take shape, and, at present, the larger critical and cultural reception of comics in North America is encouraging. However, a number of factors make it difficult to speak of the field as anything other than nascent. These include the weakness of the field's institutional footing (in the form of academic programs devoted to comics study), a lack of consensus regarding critical standards for published work, and, above all, a lack of dialogue regarding the disciplinary status of the field. In fact comics studies has no disciplinary status in the traditional sense, that is, no clear, cohesive, and selfcontained disciplinary identity. I am not about to argue that the field requires such an identity. Rather, I would argue that comics studies cannot have such an identity, for two reasons: one, because the heterogeneous nature of comics means that, in practice, comics study has to be at the intersection of various disciplines (art, literature, 
communications, etc.); and, two, because this multidisciplinary nature represents, in principle, a challenge to the very idea of disciplinarity. Comics studies forcefully reminds us that the disciplines cannot be discrete and self-contained; in effect, the field defies or at least seriously questions the compartmentalizing of knowledge that occurs within academe. Inevitably, comics studies will bring together various disciplines and methodologies in a workspace that is at least multidisciplinary if not truly interdisciplinary. Ideally, it will go further, fostering collaboration and colleagueship across disciplinary and programmatic boundaries.

3 Personally, I find this an exciting prospect. In any case, multidisciplinarity is a working fact of comics studies in North America, the field having coalesced around multidisciplinary conferences such as the Comic Art \& Comics area of the Popular Culture Association, the Comic Arts Conference, and the International Comic Arts Forum, and multidisciplinary journals such as Inks (1994-97), the International Journal of Comic Art, and ImageTexT: Interdisciplinary Comics Studies. All of these forums are predicated, some implicitly, some explicitly, on at least a vague sense of multidisciplinarity. Yet there remains in the field a major obstacle to genuine interdisciplinary collaboration: comics scholars have not yet had, and I submit urgently need to have, a concerted discussion (both in writing and in person) about the challenges and opportunities posed by the field's multidisciplinary nature. If comics studies cannot be a narrowly circumscribed discipline in the traditional sense, if it cannot derive its identity from disciplinary specialization, then arguably it must make up for this lack of disciplinary status by becoming intentional about how it accommodates and takes advantage of the differences among its participating disciplines. In short, comics studies in North America is overdue for a frank dialogue about the methodological and ideological differences within it. There are crucial differences between, say, an art historian studying the development of caricature and a literary critic studying contemporary comic books under the aegis of postmodernism. There are differences between a journalism scholar studying the impact of political cartooning and a cultural studies scholar studying the relationship between anime and manga. There are differences between those studying comics as artists' books (limited production) and those studying comics as popular cultural artifacts (mass production). These differences do not mean that comics studies can have no firm identity or institutional footing, but they do mean that we continually risk talking at crosspurposes without realizing it. If comics studies is to bring together different disciplines, it would behoove the field to do this in a conscious way.

4 It is one thing simply to state that comics study is "interdisciplinary," and another to think concretely about the relationships among disciplines as they interact within the field. Here a distinction needs to be made between mere multidisciplinarity and intentional interdisciplinarity. The former, as generally agreed and as defined by Julie Thompson Klein in Interdisciplinarity: History, Theory, and Practice, denotes a "juxtaposition of disciplines," an "additive, not integrative" relationship that, though it may involve work in a common environment, requires no genuine cooperation among the participating disciplines and does not offer to change or enrich said disciplines (Klein 56). Multidisciplinary arrangements tend to be ad hoc and limited, often transitory; or, alternately, the term "multidisciplinary" may be applied broadly to all education, and therefore convey no specific or urgent meaning. Undergraduate education, for example, may be viewed as multidisciplinary in the sense of being encyclopedic or eclectic (sampler-like), at least at the lower division or nonspecialist 
level. The hoped-for synthesis of knowledge occurs, if at all, in the student's mind, rather than at an institutional level (57-57). There is rarely a conscious articulation of shared methods and problems among the many participating disciplines. Interdisciplinarity, by contrast, denotes a more conscious working-together, a "teamwork," which presupposes both disciplinary awareness and a willingness to traverse disciplinary boundaries. I believe that the status of comics studies over the long term depends on working toward this kind of conscious collaboration.

Unfortunately, at times the invocation of "interdisciplinarity" may become merely a polite way of granting the incompatibility of certain approaches, while forestalling any consideration of how or indeed whether they truly are incompatible. In fact unexamined claims of multi- or interdisciplinarity may serve not as genuine invitations to interdisciplinary dialogue but as summary refusals of such dialogue: don't trouble us and we won't trouble you. Obviously, academic disciplines routinely talk across rather than to each other; one has come to expect this as a regrettable side-effect of the way we compartmentalize knowledge. What makes the question acute for comics studies is that the field's very emergence has required a series of ad hoc cross-disciplinary partnerships that have not thus far been subject to critical reflection. In order to reach critical mass intellectually and professionally, comics studies has had to take a multidisciplinary perspective, yet the overlap and tension between the various participating disciplines has not yet led to a concerted discussion, much less a coherent model, of interdisciplinarity.

6 This is not to insist that the disciplines involved in comics study have had nothing to say to each other (obviously that would be untrue), or that said disciplines are inevitably separated by insuperable differences. Nor is it my point that we must crack open some fragile truce that exists among those disciplines; it seems to me that what conflicts do exist are not so openly recognized that a "truce" has been felt to be necessary. I do not believe most comics scholars in the academy would characterize the field in terms of open conflict. Yet, though disciplinary differences within comics studies have remained largely tacit, said differences remain meaningful, and manifest themselves as difficulties or complications at every level: from the organization of conference programming and the editing of journals to seemingly minor considerations such as rhetorical style and standards of citation and documentation. Witness for example the attempt to create a single citation standard for comics study: despite efforts to bring scholars together in support of a uniform practice, different disciplinary standards continue to militate against its widespread adoption. In 1998, the Comic Art and Comics Area of the Popular Culture Association proposed a citation guide for comics similar to MLA style, assembled and edited by academic librarian Allen Ellis. This was an important step. Yet neither this guide nor any other has established a prevailing standard (see Ellis). The MLA has recently attempted to establish its own guidelines for comics citation, but of course these would apply only within the humanities, and not universally even then. Disciplinary differences continue to aggravate these very basic issues. Granted, such differences may not always be experienced as open conflict, they can and do lead to confusion and misunderstanding. My point is that one must recognize these differences before any true interdisciplinary understanding can be negotiated. Comics studies, in short, needs to develop an intentional interdisciplinarity, one that acknowledges, without merely surrendering to, the field's heterogeneous nature. 
7 Despite the important differences among its participating disciplines, comics studies constitutes a field of shared activity. Comics scholars from disparate fields do share a sense that they have something in common. Indeed comics studies constitutes a distinct genre, not so much because of shared formal conventions but because it shares a common object of study and consists of "typified rhetorical actions based in recurrent situations." This definition of genre, a seminal re-codification proposed by Carolyn R. Miller (1984) and elaborated by genre theorists since, defines a genre not by what it "is" but by what it tries to do, which is to say that social function and purpose are paramount. From this point of view, that of rhetorical genre theory, it is the social and historical circumstances of a genre that define what is important about said genre. In the words of Amy J. Devitt,

people use genres to do things in the world (social action and purpose) and [...] these ways of acting become typified through occurring under what is [sic] perceived as recurring circumstances. Within established genres, what are seen as formal conventions have developed as rhetorical acts and continue to act rhetorically. [...] In fact, genres are defined less by their formal conventions than by their purposes, participants, and subjects: by their rhetorical actions. ("Integrating" 698)

Despite their disciplinary differences, comics scholars in the academy, at least in today's North American context, share what is widely perceived to be a common set of "circumstances." These circumstances include comics' improving yet still disputed (or at least still unsure) intellectual status; the growth of cultural studies and interdisciplinary work in academia in general, which have provided a supportive context; and a desire for comics scholars scattered across disciplines to recognize and commune with each other. This basic situation is not simply a matter of objective fact but also one of shared perception, for, as Devitt points out, just as "people construct genre through situation" they also construct "situation through genre"; in other words, the relationship between genre and situation is "reciprocal and dynamic" (Writing Genres 21). In addition to this perceived situation, most comics scholars in the academy would probably go so far as to agree that they share common purposes, among them the legitimization of comics as an object of study, the development of resources for further comics research, and, obviously, the exchange of ideas relevant to specific areas or projects. Finally, these perceived, or typified, circumstances and purposes have led to rhetorical responses that can also be typified, among them gestures toward definition, attempts to position comics and comics studies vis-à-vis new or uncertain or multiple audiences (see Witek 2008, and Fischer in this very issue of Transatlantica), and, of late, elated and/or bemused recognitions of the field's "sudden" new respectability. While these responses may not constitute a genre in the narrow sense of rhetorical formula, they do constitute a genre in the sense of typified rhetorical action in response to a perceived urgency, lack, gap, imperfection, or opportunity, what Lloyd Bitzer famously has labeled an exigence (Bitzer 6).

9 An exigence as defined by Bitzer is the driving necessity that informs a rhetorical situation. Following Bitzer's much-questioned but still influential model, exigence, audience, and constraints together constitute said situation, whether the exigence is seen as objectively present or as constructed by the speaker. Many comics scholars (myself included) share an exigence that has to do with both the promise of comics studies as a nascent field and the field's current instability or perceived lack of status. Our work in turn defines, redefines, or heightens awareness of this exigence. This 
reciprocal process of responding to and constructing exigence typically imparts urgency to our work. Again, said exigence is not merely private but shared; exigence, as Miller explains, is necessarily "a form of social knowledge," a shared "construing of objects, events, interests and purposes that not only links them but also makes them what they are: an objectified social need" (157). In fact a genre, according to Miller, is precisely "a rhetorical means for mediating private intentions and social exigence." Genre serves to connect "the private with the public, the singular with the recurrent" (163). By this light, the discourse of comics studies clearly constitutes a genre. Moreover, this genre provides not simply patterns or formulas or strategies for achieving pragmatic ends. It also serves to teach us, as Miller puts it, "what ends we may have" (165). Beyond mere rhetorical formula, the genre helps us organize and make sense of the situation we are in. Indeed, as Anis Bawarshi writes, the "genre function" is a way of rhetorically constituting social reality, for genres "are not just the effect of what we do when we communicate [...] but what we actually do when we communicate, the activity itself..." (358). The emerging discourse of comics studies, then, ought to be viewed as more than simply the sum total of the effects of what comics scholars do. It is a genre that informs and shapes, if not regulates, who comics scholars are and how they understand their purposes and activities. Undertaking academic comics study means, in essence, entering into this increasingly self-conscious genre (as indeed I am doing here).

A typical feature of the comics studies genre is the attempt at definition, which by now constitutes a distinct rhetorical convention-a formula or strategy for, in essence, the initial framing of comics as an object of study. The bid for definition, beyond a cliché or helpful generic convention of academic writing (familiar from professional and student papers alike), is especially fraught in North American comics studies, where, despite a wealth of work over the past fifteen years, projects are still being presented as if the field were almost brand-new and as if the writer-researcher were introducing the subject to an audience unversed in comics (see for example Chute 2008). In fact comics scholars still do encounter situations in which they are obliged to frame comics for an unfamiliar audience (though this is becoming less necessary as word spreads). In such situations the bid for definition may work as a powerful inclusionary or exclusionary frame.

11 The perceived need for such framing is diminishing, and Anglophone comics studies has recently begun to question if not entirely forego this strategy, that is, to examine critically the impulse to assert abstract, supposedly neutral definitions of comics as an opening rhetorical gambit. A current of informed skepticism about definitions-as reductive, misleading, and/or narrowly tactical-has emerged, its first airing being perhaps Samuel R. Delany's bravura essay "The Politics of Paraliterary Criticism" (1996), in part an admiring yet also spirited rejoinder to Scott McCloud's seminal Understanding Comics (1993). Whereas McCloud proposes a single formalist definition of comics, Delany, leery of the reductiveness of such formulas, argues for local and multiple descriptions of comics instead, functional descriptions that need not aim for the airtightness, nor the transcendent ontological authority, of "definitions" once-andfor-all. Positing comics as "social objects" (the term is Lucien Goldmann's) that cannot be exhaustively defined based on formal characteristics alone, Delany rejects the bid for absolute definition as old-fashioned and self-defeating. He argues that adopting a single reified definition undersells the diversity and complexity of comics (240). Some practitioner-critics in the comics field have followed in this spirit, reasserting the 
historical richness of comics contra McCloud's ahistorical formalism. For example, Eddie Campbell has argued against defining comics in terms aloof to the actual history of their publication, reception, and use; he contends that McCloud's "obsession with [sequential] form [...] hampers a proper appreciation of the history of comic art," which in his view includes a great deal of cartooning excluded by McCloud's definition (Review 43-44). Though Campbell has said he considers Understanding Comics "one of the great graphic novels" and "a great work of fiction" (Interview 114), he has sharply criticized McCloud's and others' attempts to define comics abstractly apart from historical considerations. Such definitions, he suggests, are ultimately ideological, serving to exclude certain kinds of work and "foster conservatism" ("The Empty Jug" $n$. pag.). At the same time, they seek to claim respectability by association with other, more consecrated cultural forms, a de-historicizing move that he calls "the lowbrow colonisation of culture" (weblog, 14 Nov. 2007). Campbell's critique is complex, simultaneously asserting the historical specificity of genres and forms (i.e., the Bayeux Tapestry is not "comics") and rejecting the tendency to divide the world into "comics" and "non-comics" and dismiss the latter. Cartoonist Dylan Horrocks has mounted a similarly complex critique: on the one hand he praises Understanding Comics as "one of [his] favorite comics" and a powerful rhetorical performance, acknowledging that Mccloud's formalism "affirms and supports [the field's] longing for critical respectability and seems to offer an escape from the cultural ghetto" (page 1); on the other, he criticizes the book for "symbolically eras[ing] the history" (page 4) and "suppress[ing] alternative conceptions" of comics in favor of a formalistic essentialism (5). At the core of this critique is the recognition that definitions are necessarily "expression[s] of certain values and assumptions," and that, for all its liberatory potential, McCloud's definition of the comics form also enforces new boundaries and exclusions (1). Academics have recently brought forward this critique of, in Aaron Meskin's phrase, the "definitional project" (see for example Meskin from the standpoint of philosophical aesthetics, and Hatfield, "Defining' Comics," from the standpoint of English). Increasingly, the exclusionary force of definitions is being challenged.

However, definitions do continue to play a structuring if not occluding role in comics studies, leading to different understandings of what the field ought to include. For example, the annual call for papers for the long-running Comic Arts Conference (1992) stipulates as its working definition of comics the Mccloudian "juxtaposed images in sequence"; on the other hand, the annual International Comic Arts Forum (1995- ), for which this writer worked until 2009, calls more broadly for papers on "any aspect of comics or cartooning," including political cartoons, gag cartoons, and caricature in addition to more obviously sequential forms. If both conferences still feel obliged to define the object of study, each constructs that object at least slightly differently. Though the role of the definition, as a strategy for initial framing, has come up for an overdue critique, some of the larger concerns behind the definitional project arguably remain: questions of identity, disciplinarity, and what methodological models are most conducive to comics study. On some level, then, the comics studies genre continues to be shaped by an uncertainty that poses both an exigence and, at times, severe rhetorical constraints.

13 Indeed the genre's very object of study continues to be in dispute, a situation that affects both individual projects and the possibilities for dialogue between them. Perhaps this is why the definitional project still seems essential in some quarters: it 
may be that we are not yet at a point where we can confidently say we are beyond it. Despite (or perhaps because of) the progress made in comics studies, there continue to be substantial disagreements about the nature of, and most productive approaches to take toward, the field's object of study. Our ability to air such disagreements could be taken as a measure of said progress; after all, unearthing the root assumptions of different research agendas is prerequisite to entering into dialogue about the field's multidisciplinary nature. As example, consider the difference between comics conceived primarily as an aspect of visual culture and comics conceived primarily as a form of literature, a difference revealed by a cluster of four recent studies: Thierry Groensteen's Système de la bande dessinée (1999), as translated into English by Bart Beaty and Nick Nguyen as The System of Comics (2007); Beaty's ownUnpopular Culture: Transforming the European Comic Book in the 1990s (2007); Rocco Versaci's This Book Contains Graphic Language: Comics as Literature (2007); and, if I may, my own Alternative Comics: An Emerging Literature (2005).

System (as many readers of this journal will doubtless know) directly challenges those who would position comics as a literary form. Key to Groensteen's project is his determination to move the discussion of comics narrative out of literary and more squarely into visual culture. He argues that comics is predominantly a visual system, more precisely a way of networking images into a "spatio-topia," that is, a system of visual sites and spaces in which relationships between images are not wholly reducible to, nor capable of being paraphrased into, words. System, both an extension of and, crucially, a substantial critique of comics studies in the European semiological mode, casts itself as resisting the "logocentric tradition" or "linguistic hegemony" of semiotics, essentially arguing that study of comics as visual narrative ought to be decoupled from literature per se. By way of conclusion, Groensteen argues that the "aesthetic evolution" of recent comics "has been toward the direction of liberating the image" (163). Beaty's Unpopular Culture-authored at roughly the same time as his cotranslating of System-bears the influence of, and makes more explicit, Groensteen's argument. Showing how contemporary alternative comics production in Europe has refused the (in Pierre Bourdieu's sense) "heteronomous principle of the marketplace and championed autonomous principles of artistic production" (6), Unpopular Culture argues that those principles, increasingly, are tied to the visual arts rather than literature. In other words, the European comics avant-garde has moved past the invocation of literature as a means of legitimization and instead has incorporated techniques and media lifted from the fine arts. The "literary tendency" in European comics, according to Beaty, peaked in the 1980s, with the ascendancy of work aspiring to "a graphic novel ideal"; since then, however, the most forward-thinking comics have been characterized by a "destabilization" of the literary and a determined "turn to the visual," in effect an exaggeration and intensification of comics' visual elements. This return to the visual, as Beaty sees it, suggests that henceforth "comics will be seen as a primarily visual, rather than literary, form of communication" (249). From his point of view, this "evolution from a criterion of value with its basis in the novel to one rooted in the artist's book" is epochal, constituting "the most significant shift in the orientation of the comics field in the past century" (7). While Unpopular Culture makes this claim for European comics specifically, and does not seek to extend its argument to the other two "general regimes or markets" that Beaty sees as dominating comics publishing (Japan and the United States), the project generally rejects a literary conception of comics as too limiting. 
By contrast, Versaci's This Book Contains Graphic Language posits comics as "a true 'literature'," a position justified by an extended comparative analysis between comics and various "legitimate" (the scare quotes are Versaci's) literary and media genres covered in English studies, including autobiography, Holocaust narrative, journalism, film, and canonical literary "classics" (25). Working through a large fund of examples from both comics and non-comics, the book argues for comics' literary value, with repeated stress on the additional or "unique" capabilities of comics that allow them to treat in distinctive fashion the same weighty issues as traditional literature. The book's strategy is twofold, at once insisting on the literary comparison and yet highlighting, over and over again, comics' exceptionality. Versaci focuses on three main factors that, in his view, allow comics to address effectively not only formal but also thematic, moral, and social issues: one, the ambiguous cultural status of comics, what Versaci calls their "powerful marginality," which enables them to bypass or subvert readers' expectations; two, the self-consciousness or self-reflexivity inherent in the comics form, which he describes as an inherently self-critical and potentially thoughtprovoking capacity; and three, the distinctive poetics of comics' "graphic language" (12-14). These qualities, Versaci argues, can make comics as demanding and rewarding as canonical literature. My own Alternative Comics pursues a similar argument, albeit without the extended comparisons to traditional literary texts, positioning comics as literature and alternative comics in particular as an important nexus of literary production. While the book borrows from other disciplines, and much of it concerns the visual nature of comics, it contextualizes its concerns-including the comics form, the economics of publishing and distribution, serialization, the graphic novel, and autobiographical self-representation-in terms of the literary.

This cluster of texts reveals important differences in how scholars coming from different disciplinary perspectives conceive of their object of study. If readers will permit me a self-referential turn, I would like to tease out these differences further by discussing the critical response to Alternative Comics. To date the two responses that strike me as most provocative are those by Jan Baetens, writing for the journal Image [\&] Narrative, and Beaty, writing in dialogue with me at The Comics Reporter, a widelyread professional blog of comics news and opinion. Tellingly, both call into question the book's positioning of comics as literature. Baetens remarks:

if the literary aspect of [comics] does not result from its socially upward mobility, there must be for Hatfield other and better arguments to make a plea for its literary reinterpretation. The basic claim that the author makes in this respect is that comics [...] represent a form of literature, since they suppose a form of (very complex) reading. [... According to Hatfield,] the reading of an image is no less coded than that of a text, and this reading transforms a comic, and certainly an alternative comic whose decoding is never automatic or "naturalized," into a form of literature. I am personally less convinced by this argument, which seems rather oblivious of the social implications of the notion of "literature" (not everything that has to be "read" is literature) and the practical confusion between coded reading of images on the one hand and literature on the other hand does not seem very helpful, unless of course one's aim is the upgrading of the genre (but this would be in contradiction with the [book's] desire to firmly root the alternative comics production within the comics industry). (Baetens, n. pag.)

17 Part of what Baetens admires about the book, evidently, is its positioning of comics in the context of their production, distribution, and reception. This positioning, he suggests, is at odds with the book's overall framing of comics as literature. Most 
interesting to me is Baetens' assertion of social context, that is, his sense that to claim comics as "literature" always and inevitably has social implications and that a bid for social "upward mobility" might be compromising the book's argument. For Baetens the connotation that "literature" means "culturally elevated" is inescapable, and, it seems, unwelcome.

Beaty, writing as part of a critical exchange with me at The Comics Reporter, poses a similar question, "Are comics really a literary form in your view, or is the title merely superior to 'An Emerging Narrative Form'?" My reply, that "the study of literature ought to include the popular, the visual, the liminal and uncategorizable," prompted this response:

you have an uncommonly catholic notion of what constitutes "literature" [...]. This helps to remove the dogmatism from the issue, I think, but it also raises the question: if so much of culture can be subsumed under the rubric of literature, is there any sense in calling it literature? That is, do we have to sacrifice too much specificity in order to regard comics as a literary form? Once we can qualify wordless culture (which comics can be, as you point out in the book) as "literary," have we lost all sense of what the term means? And should we want to? Maybe I can put it this way: Has literary studies overstayed its welcome? If literary studies is going to incorporate art exhibitions, have we reached the end of literature as a useful concept? (Beaty and Hatfield, n. pag.)

Beaty then goes on to extend the argument of Unpopular Culture, that comics' criteria of value have shifted from the literary to the visual arts, to comics in the United States, citing American avant-garde works such as Paper Rodeo, TheGanzfeld, and Kramer's Ergot that, in effect, are catching up to European work and that point to a seeming divide between a primarily "literary" and a primarily "visual" camp in comics. ${ }^{1}$

20 My point in quoting these readers, who after all are sympathetic, is not to defend against their remarks. Certainly the thrust of their questioning has nothing to do with casting doubt on the artistic importance of comics. Rather, it has to do with questioning the importance and expansiveness of literary culture itself, more particularly my claim that "literature" can be open enough to accommodate the kind of work that Alternative Comics tries to accomplish. I take it that, for Baetens and Beaty alike, it is not comics' fitness for literary status that comes up for reconsideration so much as the very category of the literary itself. Their comments hit on questions of disciplinarity that are muted but crucial in Alternative Comics, namely two questions: one, the extent to which a literary conception of comics can usefully encompass primarily or exclusively visual material; and, two, whether something vital stands to be lost in importing comics into literary culture.

21 I had hoped it would be clear from the book's content that Alternative Comics, its subtitle An Emerging Literature notwithstanding, does not seek to assimilate comics into the canons of literature in such a way as simply to reinforce or marginally expand those canons. Implicit in the book, or rather only occasionally explicit, is both resistance to the unreflective absorption of comics into literature as traditionally defined and an espousal of comics as a genre of visual literature-a term that, as I understand it, need not collapse comics into existing literary paradigms but rather bids to expand the whole notion of what constitutes the literary. By way of introduction, the book acknowledges that comics constitute "an unusual kind of literature [that] should not be carelessly subsumed into prevailing models" (xiv). By way of conclusion, it cautions that "importing comics into prevailing canons of literary value, without regard to their 
special formal characteristics and the specialized circumstances of their making, may mystify their origins and impoverish our appreciation of the medium" (162). Despite this, Alternative Comics insists on framing comics in literary terms, not in a mere bid for status, but, from my point of view, as an incipient attack from within on hidebound ideas of what literature itself is or should be. I submit that the proposition "comics are literature" ought not merely to confer new status on comics; it ought to redound on literature itself, calling for renewed attention to the operations of exclusion and canonization that structure English studies as a discipline.

A similar agenda seems to underlie Versaci's Graphic Language. Despite the book's structuring insistence on comparing comics to "legitimate" literary texts, Versaci argues that comics "invite us to think more deeply about how literary merit is accorded and why this is a question worth pursuing" (28). Comics, he concludes, have the capacity to "complicate" our sense of what literature is:

All of the incarnations of the comic book that I have discussed throughout this book

[...] help to upend the notion of "literature" as an inviolable model that must adhere to certain dimensions. What we are in need of is a new model of the "literary" [...]. (209)

Speaking as a teacher, Versaci adds that he assigns comics as "a way of provoking my students to think more deeply about the alleged sanctity of [the literary] canon and how artistic value is accorded to particular media, genres, or titles" (209). In sum, Versaci's book, like Alternative Comics, implicitly pushes against the boundaries of the literary as conventionally delimited. The point of all this is that, like "comics" itself, "literature" is a moving target, subject to reevaluation and change by its inclusion of comics just as comics are subject to reevaluation and change by being included in the literary.

An obvious rejoinder to this position might be that comics study is more properly about cultural studies than literature. To this my answer has to be complex: yes, work on comics is indeed part of and beholden to cultural studies; however, the meaning of that answer is subject to misconstrual insofar as cultural studies continues to be seen as uninterested in, if not positively averse, to aesthetics (despite recent attempts to recuperate the aesthetic as a focus, such as Michael Bérubé et al.'s The Aesthetics of Cultural Studies in 2005). The general perception seems to be that, as one of my colleagues has put it, "aesthetics really isn't a factor in contemporary cultural studies." While this reflects too limiting a view of cultural studies, I do often find, in conversations within my discipline, that the term "cultural studies" serves simply as a shorthand for the extra-literary: stuff that scholars in English studies may freely pursue but without actually making claims on the aesthetic or challenging the primacy of literature. This (mis)understanding of cultural studies, I would argue, is problematic for comics, since responsible study of comics and comics-reading demands at least some minimal understanding of the aesthetic and formal dimensions of comic art, areas that, until the past fifteen years or so, have been woefully under-served by academia. Ironically, then, though the cultural studies movement is the very thing that has rendered the academic study of comics recognizable and supportable, too often cultural studies is narrowly understood within the discipline of English as somehow handicapping, or putting a derogatory asterix beside, its objects of study, placing them at an implicit remove from "literature." Therefore projects like Alternative Comics and Versaci's Graphic Language, rather than abandoning the term literature, set out to reappropriate it from the inside. This is a reminder that disciplines are continually 
subject to change; literary scholars touting comics "as" literature are, or should be, involved not just in a bid for respect but in a spirited reassessment of what their discipline is about. In a sense, labeling comics as literature entails the discipline of English studies arguing with itself.

Obviously, asserting that comics can be literature is, in part, a way of asserting that they are artistically serious and important, that they constitute a distinct and rich narrative tradition, and that they may productively be studied with the same earnestness as scholars would bring to bear when reading any other kind of text. It may turn out that insisting on the word "literary" is the wrong, or a misleading, way to go about pressing these claims. Admittedly, literary culture is a specific historical formation with its own beliefs, presumptions, and habits-in short, its own ideology-a formation that has, until now, emphatically not included such things as comics. The question is whether that formation is elastic enough, or generous enough, both to admit comics and to engage in the self-reflexive dialogue that admitting comics ought to provoke. It remains for me to point out that a great deal of what is now subsumed under "literature"was at one time pointedly excluded from the literary (the modern novel being probably the most notorious example). The history of literary study, in this view, has to do with the willed forgetting, then belated partial rediscovery, of the very popular traditions that have fed into literature. Comics could become another such example of this pattern of loss and recovery, or, on the other hand, they might never "make it"; their ambiguous status as visual narrative and popular culture might continue to place them beyond the purview of the literary. For that matter, the academic study of literature is itself widely considered to be under threat, or in the process of being rendered obsolete, a source of debate within the discipline for years (see Scholes for a flashpoint) and continually a source of op-ed writing and stancetaking (see Deresiewicz for a ripe example). My point is that comics study within English studies represents both a point of negotiation between English and other disciplines and a point of contestation in English studies itself. Our disciplines are never static, neither with respect to each other nor within themselves. I submit that one of the greatest benefits of interdisciplinary comics study is the way contact with scholars from various other disciplines may inform and enliven the way we talk about change within our own respective disciplines.

Disciplines have potential for change, and indeed do change all the time, albeit typically at a slow pace. Inspiring scholars to reflect on and seek change in their respective disciplines is part of the potential of comics studies as an interdisciplinary project. After all, being in continual close contact with scholars in other disciplines ought to have some effect on the way we envision and do our own work. If part of the attraction of comics study lies in the comics themselves, another part surely lies in the way comics can potentially force us out of our ossified habits and get us to reconsider some of the fundamental assumptions of our disciplines. This is how I see comics from my perspective as a scholar-teacher in English studies: comics have the potential to call English out of its habits and into fresh examination of certain structuring assumptions of the discipline, for example the putative differences between words and pictures, or between writing and drawing, or between literature and popular culture. By the same token, comics studies has the potential to bring scholars from other disciplines into dialogue with English. 
27 If comics studies is to realize this potential, then arguably it needs to enter into conversation about how to transition from mere multidisciplinarity to genuine interdisciplinarity. We ought to ask, what kind or kinds of interdisciplinary work does comics studies practice, or have the potential to practice? How might the interdisciplinary potential of comics studies be described? To this end, I find it helpful to invoke Lisa R. Lattuca's (2003) typology of interdisciplinary work, a typology based on the different kinds of research questions that underlie and motivate said work. This typology is, Lattuca cautions, descriptive rather than evaluative in nature, which is to say that she intends no hierarchy or preference (6). Briefly, the four categories of interdisciplinarity that Lattuca posits are as follows:

Informed disciplinarity consists of disciplinary teaching and disciplinary research that reach out occasionally to other fields, borrowing "methods, theories, concepts, or other disciplinary components" in order to address questions that are nonetheless native to the scholar-teacher's home discipline (6). Informed disciplinary teaching "may be liberally sprinkled with examples from other disciplines," but, says Lattuca, "these examples are not central." Informed disciplinary research tends to be "limited to borrowing of disciplinary methods" (8-9). This category typically involves spontaneous problem-solving without a fundamental change of perspectives.

Synthetic interdisciplinarity consists of research and teaching prompted by questions that "link" disciplines, either because those questions are located "in the intersections of disciplines" or because those questions are located "in the gaps between disciplines" (7). Synthetic interdisciplinary work, then, focuses on either issues that are shared among disciplines or issues that are not yet seen as belonging to any discipline. In such work, as Lattuca says, "the contributions or roles of the individual disciplines are still identifiable," though the questions posed are not seen as native to a single field (7).

Transdisciplinarity consists of research and teaching that pose questions that reach "across" disciplines in hopes of discovering "underlying structures or relationships" (12) and thus "developing an overarching synthesis" (7). In transdisciplinary work (common examples include Marxism and sociobiology) the constituent disciplines provide, not components, but "settings in which to test the transdisciplinary concept, theory, or method" (7). The disciplines are thus "subsumed" under a larger superdiscipline or super-theory. Proponents may advocate these super-disciplines as replacements for extant disciplines, or may simply hope that transdisciplinarity will bring greater coherence to multidisciplinary work (13).

31 Lastly, conceptual interdisciplinarity consists of research and teaching that pose questions that fundamentally have no "compelling" or exclusive disciplinary basis (7) and indeed may be seen as challenging the disciplinary system. Conceptual interdisciplinary courses often have no disciplinary "home," and are not organized so as to privilege particular disciplinary perspectives (13-14). Conceptual interdisciplinary research rejects the commonplace idea of interdisciplinarity as simple "borrowing" and instead strives to create, as one of Lattuca's anonymous informants puts it, "new intellectual space" (14-15). Implicit in conceptual interdisciplinarity, according to Lattuca, is a critique of the disciplines as traditionally defined. In contrast to transdisciplinarity, which favors the search for similarities and for concepts that are "transportable" from one discipline to the next, conceptual interdisciplinarity goes as far as questioning the very "legitimacy and usefulness of [...] disciplinary boundaries," casting such boundaries as social or bureaucratic artifacts rather than essential divisions of 
knowledge (17). Conceptual interdisciplinarity, then, includes the possibility that interdisciplinarity may transform the disciplines themselves (15).

These four categories-and Lattuca grants that further study may uncover further categories-are not mutually exclusive, nor are they meant to label the individual scholar or the entirety of her/his scholarship. Rather, the categories apply to particular projects and situations, and a single scholar may participate in all of them (8). Comics studies arguably partakes of at least three of these categories, and potentially all four. First off, "informed disciplinarity" would seem to be a given in comics studies: since comics are generally understood to be visual narratives, and since they often (if not typically) involve collaboration between image and written text, comics studies tends to assume as a minimal requirement some familiarity with critical strategies for approaching both visual art and written, if not literary, discourse. At the least, therefore, informed disciplinarity should probably be expected of comics studies. In informed disciplinarity, methods and concepts are borrowed from other fields in order to address essentially disciplinary questions (say, questions of literary or art criticism). For example, an English teacher would likely be expected to be able to help students analyze the visual dimensions of comics, even if focused primarily on disciplinary questions such as narrative structure, characterization, rhetorical strategies, or genre. Conversely, an Art or Art History teacher would probably be expected to have recourse to narrative theory if not literary criticism when discussing comics' sequential elements, even if focused primarily on disciplinary questions such as pictorial composition, style, medium, or graphic design. At the least, outreach to or borrowing from other disciplines would seem to be essential to the field.

"Synthetic" interdisciplinarity as defined by Lattuca also applies. Indeed, I would argue that comics studies thus far has been de facto synthetic if not integrationist in character. At the institutional level-at conferences like the PCA or the ICAF, or in journals like ImageTexT and the IJOCA-comics studies has been simply the sum total of "links" between the various disciplines interested in comics. Obviously, comics' status as visual texts places them at the intersection or overlap between disciplines; they "belong" to several different fields. Alternately, we might say that comics' status as visual texts, or as popular culture, places them "in the gaps between disciplines," which is to say that, until fairly recently, comics have hardly "belonged" to any academic field at all. They have fallen through the cracks. Either way, comics by their nature pose research questions that link disparate fields. Comics studies today, to borrow words from another of Lattuca's informants, "uses methods and concerns and theories from different disciplines, and [...] also ignores the fact that there are gaps in method and theory in each of the home disciplines" (11).

"Transdisciplinarity," as Lattuca defines it, is perhaps the category most difficult to apply to present-day comics studies. While comics studies poses questions that reach "across" disciplines, its common object of study, comics, does not in itself constitute an overarching synthesis, that is, a transdisciplinary conceptual framework comparable to Lattuca's examples (Marxism, sociobiology, general systems theory). Indeed, as we've seen, different subgroups within comics studies do not even conceptualize their common object of study in a common way. Comic studies does not presuppose a unifying theory, nor promise the creation of a super-discipline that would replace extant disciplines (13). However, the field of comics studies may provide a setting in which to "test" the transdisciplinary theories of another field, namely, those of word 
and image studies. (This is not to say that comics studies is necessarily a subfield of word and image studies, but simply that comics studies overlaps, can inform, and can learn from word and image studies.)

"Conceptual" interdisciplinarity is the most provocative perspective from which to describe what could happen in comics studies. In conceptual interdisciplinarity, as I understand it, the research questions have no distinctive disciplinary basis, disciplinary boundaries are under semi-erasure, and the interdisciplinary work reaches beyond borrowing in an attempt to carve out a new intellectual "space." Comics studies defined in this way would constitute a de facto critique of disciplinarity: a serious questioning of the academic compartmentalization of knowledge. This is not to promise that comics studies so defined would entirely collapse the disciplinary and bureaucratic boundaries that separate scholars in the academy, or that comics scholars would lose their affiliations with their home disciplines; however, comics studies could encourage a selfreflexive questioning of these boundaries and affiliations, and the comics scholar's interdisciplinary work could become a way of helping to transform her/his discipline from within.

At the heart of the category "conceptual interdisciplinarity" is a tension that warrants a closer look. Implicitly, conceptual interdisciplinarity would seem to gesture toward a radical critique of the disciplinary system. Such a critique is put forth by, for example, Martin L. Davies, who, in a chapter-cum-manifesto in Breaking the Disciplines (2003), advocates the idea of the "ecology of knowledge," that is, a disposition to knowledgemaking that refuses conventional disciplinarity and offers a model "for relating apparently disparate phenomenon with each other" (25). Said model, or mode of reflection, encourages a self-reflexive awareness of the very principles of knowledge production. The ecology of knowledge, writes Davies, is a "questioning social and intellectual practice" that inevitably resists, must resist, forms of knowledge-making based merely on deference to authority, specialization, theorization (which Davies casts as an extreme form of specialization) and commodification (11-13). Provocatively, Davies argues that such an intellectual ecology "must dissociate itself from that new variant of specialization, inter- or multidisciplinarity," which, he says, "involves just the purely technical coordination of technical specializations." Davies sees interdisciplinarity as merely "aim[ing] to define larger, common patterns of coherence for partial interests" (25). He argues instead for a recuperation of that "much-maligned intellectual stance," eclecticism, which he describes as a polemical position, not a "program"; an "antidote" to extreme specialization, not another variety of technical expertise (25-26). Indeed eclecticism is an approach disparaged by many scholars of interdisciplinarity. An unexamined eclecticism, I would argue, is the current condition of comics studies.

Davies' hoped-for radical eclecticism contrasts strikingly with the claim, put forth elsewhere in Breaking the Disciplines, that disciplinary specificity remains essential even in the context of transdisciplinary dialogue. Helen C. Chapman's chapter in Breaking, while describing disciplines as "inherently conservative" and even as (quoting Diane Elam) "a containment strategy designed to [...] promote the uncritical acceptance of the institution" (40), argues that the disciplines each have distinctive and complementary roles to play vis-à-vis each other. Building from Deleuze and Guattari's What is Philosophy?, Chapman stipulates that

each discipline has a distinct, non-hierarchical role to play in relation to another.

Each discipline has a mode of exploration which is appropriate to it. [...] To criticize 
one for not doing what another does is to fail to recognize the necessary specificity of the disciplines. On this one point Deleuze and Guattari and the disciplinary police concur: it is necessary to hold onto some sense of identificatory specialization, for otherwise knowledge-claims would be reduced to utter relativism. (50-51)

Chapman, while calling for non-hierarchical dialogue between the disciplines, nonetheless maintains that the aim of such dialogue is not "to effect a synthesis" of disciplines but to encourage "productive engagement" and offer "a different assemblage" (52). I interpret this to mean that we should not expect the disciplines to dissolve into one another in either a vast transdisciplinary synthesis or a scorchedearth rejection of disciplinarity as such. Indeed Lattuca points out that conceptual interdisciplinarity, despite its criticism of the existing system, may not lead to a thorough integration of disciplinary perspectives, due to essential differences among the disciplines in terms of methodology, epistemology, and ideology (16-17). Chapman's remarks suggest that said differences need to be honored, so that each discipline can play its distinct (and neither lesser nor greater role) in interdisciplinary dialogue. By this light, a willingness to traverse disciplinary boundaries and engage in "teamwork" first requires an understanding of disciplinarity: one's home turf, so to speak. Nonetheless the category of conceptual interdisciplinarity would seem to imply, at the least, continual questioning of the disciplinarity system, ongoing self-critical engagement with one's own discipline and its approach to knowledge production, and continual expeditioning across disciplinary borders. Were comics studies to take this path, that of conceptual interdisciplinary, the field might come to occupy a central place in James Chandler's hoped-for "rethinking" and restructuring of the disciplinary system. ${ }^{2}$

In other words, comics studies might become the very opposite of a critical backwater; it might take part in the ongoing and essential reexamination of how, by whom, and under what auspices knowledge is produced in academe. In any case, comics studies, to thrive, must find a stable conceptual basis that is in no way interchangeable with conventional disciplinarity. In order to address seriously the lack of institutional footing for comics studies, and in order to raise standards in the field (which need not mean imposing one rigid set of standards on scholars from multiple disciplines), comics scholars need to develop and make explicit their commitment not simply to multi- but to interdisciplinarity. We need to articulate a rigorous pluralism-self-aware, synthetic, and questioning-if the field is to flourish. We might begin to do this by analyzing our differences in public forums, calling together areas, discussion groups, or caucuses within conferences, appointing disciplinary reviewers and/or sub-editors at journals, working toward shared editorial standards (though not monolithic editorial practices), and undertaking collaborative projects across disciplinary lines, such as genuine team (not just serial or round-robin) teaching. Such moves are, I submit, prerequisite to gaining a more secure institutional footing for and raising standards in comics studies. Collaboration based on awareness of our differences can help us bring cohesiveness to a field that, by its nature, will never fit tidily inside one set of disciplinary boundary lines. 


\section{BIBLIOGRAPHIE}

BAETENS, Jan. Rev. of Alternative Comics: An Emerging Literature by Charles Hatfield. Image [\&] Narrative: Online Magazine of the Visual Narrative 13 (Nov. 2005). Web. 08 June 2010.

BAWARSHI, Anis. “The Genre Function.” College English 62.3 (Jan. 2000): 335-360. Print.

BEATY, Bart. Unpopular Culture: Transforming the European Comic Book in the 1990s. Toronto: University of Toronto Press, 2007. Print.

BEATY, Bart, and Charles HATFIELD. "Let's You and Him Fight: Alternative Comics - An Emerging Literature." The Comics Reporter: Tom Spurgeon's Web site of comics news, reviews, interviews and commentary. 14 Nov. 2005. Web. 08 June 2010.

BÉRUBÉ, Michael, ed. The Aesthetics of Cultural Studies. Malden, MA, and Oxford: Blackwell, 2005. Print.

BITZER, Lloyd. “The Rhetorical Situation.” Philosophy and Rhetoric 1 (Winter 1968): 1-14. Print.

CAMPBELL, Eddie. Review of The Adventures of Obadiah Oldbuck by Rodolphe Töpffer and Stuff and Nonsense by A. B. Frost. The Comics Journal 260 (May/June 2004): 42-47. Print.

--- . Interview with Dirk Deppey. The Comics Journal 273 (Jan. 2006): 66-14. Print.

--- . “The Empty Jug." Weblog post. The Fate of the Artist. 09 June 2007. Web. 08 June 2010.

--- . Weblog post. The Fate of the Artist. 14 Nov. 2007. Web. 08 June 2010.

CHANDLER, James. "Critical Disciplinarity." Contribution to "The Future of Criticism: A Critical Inquiry Symposium.” Critical Inquiry 30:2 (Winter 2004): 355-360. Print.

CHAPMAN, Helen C. "Becoming Academics, Challenging the Disciplinarians: A Philosophical CaseStudy." Davies and Meskimmon 35-58. Print.

CHUTE, Hilary. “Comics as Literature? Reading Graphic Narrative.” PMLA 123.2 (March 2008): 452-465. Print.

DAVIES, Martin L., and Marsha MESKIMMON, eds. Breaking the Disciplines: Reconceptions in Knowledge, Art and Culture. London and New York: I. B. Tauris, 2003. Print.

DAVIES, Martin L. “Thinking Practice: On the Concept of an Ecology of Knowledge.” Davies and Meskimmon 9-34. Print.

DELANY, Samuel R. "The Politics of Paraliterary Criticism.” New York Review of Science Fiction Vol. 9, Nos. 2-4 (October-December 1996). Rpt. inShorter Views: Queer Thoughts \& The Politics of the Paraliterary. Hanover and London: Wesleyan University Press / University Press of New England, 1999. 218-270. Print.

DERESIEWICZ, William. "Professing Literature in 2008." The Nation. 11 March 2008. Web. 08 June 2010.

DEVITT, Amy J. "Integrating Rhetorical and Literary Theories of Genre." College English 62.6 (July 2000): 696-718. Print.

---. Writing Genres. Carbondale: Southern Illinois University Press, 2004. Print.

ELLIS, Allen. "Comic Art in Scholarly Writing: A Citation Guide." International Journal of Comic Art 1.1 (Spring/Summer 1999): 33-41. Print. Also available at ComicsResearch.org. Web. 08 June 2010. 
FISCHER, Craig. "Worlds within Worlds: Audiences, Jargon, and North American Comics Discourse.", Transatlantica [Online], American Shakespeare / Comic Books, 2010:1, http:// transatlantica.revues.org/4919.

GROENSTEEN, Thierry. The System of Comics. Trans. Bart Beaty and Nick Nguyen. Jackson: University Press of Mississippi, 2007. Trans. of Système de la bande dessinée. Paris: Presses universitaires de France, 1999. Print.

HALBERSTAM, Judith. “Animation.” Profession (2009): 44-49. Print.

HATFIELD, Charles. Alternative Comics: An Emerging Literature. Jackson: University Press of Mississippi, 2005. Print.

--- . "Defining' Comics in the Classroom, or, The Pros and Cons of Unfixability." Teaching the Graphic Novel. Ed. Stephen E. Tabachnick. New York: Modern Language Association of America, 2009. 19-27. Print.

HORROCKS, Dylan. "Inventing Comics: Scott McCloud's Definition of Comics." The Comics Journal 234 (June 2001): 29-39. Rpt. Hicksville: The Website of Dylan Horrocks. Web. 08 June 2010.

KLEIN, J. T. Interdisciplinarity: History, Theory, and Practice. Detroit, MI: Wayne State University, 1990. Print.

LATTUCA, Lisa R. "Creating Interdisciplinarity: Grounded Definitions from College and University Faculty." History of Intellectual Culture 3.1 (2003): 1-20. Print.

MESKIN, Aaron. “Defining Comics?” The Journal of Aesthetics and Art Criticism 65.4 (Fall 2007): 369-379. Print.

MILLER, Carolyn. “Genre as Social Action.” Quarterly Journal of Speech 70 (May 1984): 151-176. Print.

SCHOLES, Robert. The Rise and Fall of English: Restructuring English as a Discipline. New Haven: Yale University Press, 1998. Print.

VERSACI, Rocco. This Book Contains Graphic Language: Comics as Literature. New York: Continuum, 2007. Print.

WITEK, Joseph. “American Comics Criticism and the Problem of Dual Address." International Journal of Comic Art 10.1 (Spring 2008): 218-225. Print.

\section{NOTES}

1. At this juncture Kramer's Ergot (2000-) is probably the best-known of the avant-garde ventures named here. A kaleidoscopic comics/graphics anthology edited by Los Angeles-based cartoonist Sammy Harkham, Kramer's has appeared sporadically in a variety of formats, most recently a huge (16 x 21 inch)compendium of short stories and one-page strips published in 2008 (issue 7). It is known for its high production values, nonlinear and at times ostensibly non-narrative content, and what might be characterized as an aesthetics of collision, in which shockingly disparate works are jammed up against each other in dizzying profusion. Harkham has likened his editorial process to assembling musical mix tapes or CDs for a friend. In any case, Kramer's has been tagged as an ideological successor to RAW magazine's 1980s avant-gardism; even RAW's Art Spiegelman has acknowledged the kinship. The Ganzfeld (2000-2008), an eclectic, genre-defying journal edited by Dan Nadel and colleagues, reflects an equally idiosyncratic editorial approach, one carried on recently in the line of books published by Nadel's Brooklyn-based company PictureBox, known for its diverse catalog of comics, art books, and limited-edition publications. PictureBox's lavish 
treatment of iconic artists like Gary Panter and its quixotic approach to format hark back, again, to the RAW era. Nadel and associates maintain the Comics Comics blog and occasional print magazine, which represent a catholic approach to comic art, one that is indifferent to consecration under the banner of "literature" or the graphic novel. Both Nadel and Harkham have resisted the partitioning and selective gentrification of the comics field, and they have been identified as standard-bearers of a new comics avant-garde (even though admiration of commercial cartoonists from the past is a major part of their aesthetics). Their publications share with the European avant-gardists discussed in Beaty's Unpopular Culture a devotion to material form and to highly personal graphic approaches that at times push the boundaries of legibility. In these works intensity is highly prized, as is the artist's creation of a unique visual idiolect; the supposed distinction between "comics" and "non-comics" holds no terror and is often traversed.

2. This essay was drafted prior to the publication of the Modern Language Association's Profession annual in 2009, which contains a provocative challenge to disciplinarity in the form of Judith Halberstam's essay "Animation." Halberstam too argues that disciplinarity is a containment strategy, a technique of power that relies on and continually reinforces "normalization, routinization, convention, tradition, [and] regularity" (45). The results of this strategy, she maintains, "are now losing relevance and failing to respond either to real-world knowledge projects or to student interests" (45). In response, Halberstam favors "abandon[ing] our disciplinary identities" and embracing what she calls illegibility, that is, fugitive knowledge practices that short-circuit the bureaucratic ordering and manipulation of intellectual work. Drawing on James C. Scott, she argues for practical and eclectic forms of knowledge that privilege "mutuality, collectivity, plasticity, diversity, and adaptability" (46). While I do not fully share Halberstam's enthusiasm for "unprofessionalization" and antidisciplinarity, I like her description of her own practice as "wandering, meandering, getting lost, and falling short" (44) - in sum, "disciplinary infidelity" (46). The implications of this argument should be taken up and debated by comics scholars, because comics studies has arrived at precisely the moment when the humanities are facing a profound crisis in relevance.

\section{AUTEUR}

\section{CHARLES HATFIELD}

California State University 